\title{
水平正方形流路内の三次元複合対流に生ずる逆流についで （三方加熱・冷却流路の場合）
}

\author{
鳥 山 孝 司*1, 一 宮 浩 市* \\ Reverse Flow on Three-dimensional Mixed Convection \\ in a Horizontal Square Duct \\ (In Case of Three Heated and Cooled Walls of the Duct) \\ Koji TORIYAMA*2 and Koichi ICHIMIYA \\ ${ }^{* 2}$ Department of Research Interdisciplinary Graduate School of Medicine and Engineering, \\ University of Yamanashi, \\ 4-3-11 Takeda, Kofu-shi, Yamanashi, 400-8511 Japan
}

\begin{abstract}
Effects of the reverse flow on heat transfer and flows in a horizontal square duct were examined numerically and experimentally for various inlet fluid temperatures. The working fluid was water. This analysis was performed in two cases. In the first case, wall temperature $\left(T_{w}=60^{\circ} \mathrm{C}\right)$ was higher than the inlet temperatures $\left(T_{0}=10 \sim 50^{\circ} \mathrm{C}\right)$. In the second case, wall temperature $\left(T_{w}=5^{\circ} \mathrm{C}\right)$ was lower than the inlet temperatures $\left(T_{0}=10 \sim 40^{\circ} \mathrm{C}\right)$. In the numerical analysis, the SIMPLE procedure and QUICK scheme were used to solve the governing equations through a control volume. The temperature dependence of kinetic viscosity and thermal conductivity of water was considered. In the experiment, the flow was visualized by a dye injection method. Results present that a reverse flow appears on the upper wall in the first case and on the other hand it does on the bottom wall in the second case. The size of the flow reversal increases linearly with the product of the Richardson number $R i\left(=G r / R e^{2}\right)$ and Prandtl number $\operatorname{Pr}(=\nu / a)$. The heat transfer behavior was discussed corresponding to the flow.
\end{abstract}

Key Words: Mixed Convection, Reverse Flow, Entrance Temperature, Numerical Analysis, Dye Injection Method, Thermal Performance

\section{は じめ ほ}

複合対流は, 微小機器の冷却, 熱交換器, CVD 炬 など幅広く利用されてきている. 特に微小機器の冷却 に関しては, 近年の微細加工技術の進歩に伴い, 機器 の小型化が進み, 比較的低いレイノルズ数域での解析 が必要不可欠となっている.

複合対流の特性については Gebhart ら ${ }^{(1)}$ がまとめて いるが, 最近では三次元特性に重きがおかれている研 究が多い. 功刀ら ${ }^{(2)(3)}$ は, 水平正方形流路について数 值解析を行い, 流路上壁に生ずる逆流域（剥離泡）の 発生機構を明らかにし, 剥㱋泡による熱伝達の鈍化や, 圧損と熱伝達増加率の対応について報告している. ま た, 坂元ら ${ }^{(4)}$ は, 上述の解析に対応する可視化実験を 行い, 流れの構造が数值解析結果とほぼ一致し, 剥離 泡長さは $\operatorname{Re}$ の低下及び流入温度と壁温との温度差 $\Delta T$ の増加に伴って非線形的に増大することを明らかにし た.しかし, 熱的境界条件に対する逆流長さの定量的

* 原稿受付 2004 年 3 月 18 日.

*1 正員, 山梨大学大学院医学工学総合研究部(画400-8511 甲 府市武田 4-3-11)

E-mail : toriyama@yamanashi.ac.jp
評価, 伝熱特性への影響についてはまだ十分に評価さ れておらず，逆流が複合対流の伝熱流動に与える影響 について, さらに検討する必要がある.

逆流現象に関しては, 内藤ら ${ }^{(5)}{ }^{(6)}$ が, 傾斜のある平 行平板間の複合対流について二次元数值解析を行い, 助走域の速度分布が自然対流の影響を受けてひずみ, 逆流が生じることを報告している. また，逆流現象が 生じる際の $R a / R e$ の臨界值についても検討を行ってい る. Cheng $ら^{(7)(8)}$ は, 垂直矩形ダクトについて三次元 楕円型数值解析を行い, 流路内に生じる逆流の強さが $G r / R e$ とダクト断面のアスペクト比に依存することを 明らかにした。 また, Barletta ら ${ }^{(9)}$ は $G r / R e$ と逆流強 さの関係について詳細に検討を行っている. 王ら ${ }^{(10)}$ は 液体金属を対象として等温水平円管について解析を行 い，加熱開始部付近の上部に逆流が発生することを明 らかにした．また，Wang ら ${ }^{(11)}$ は，作動流体のPrを変 えて解析を行い, $\operatorname{Pr}$ の減少とともに，その逆流域は増 大することを明らかにした．著者ら ${ }^{(12)}$ は，側壁・下壁 伝熱における流路について流入温度を変化させて数值 解析及び可視化実験を行い，流体が冷却される場合で は, 流路下壁に剥離泡が発生することを見い出した。 
本研究では, 水平正方形流路内の複合対流について, 流体が流路壁により加熱される場合と冷却される場合 の 2 つの場合に分け, 流入温度と壁温との温度差を幅 広く変化させて, 数值解析及び可視化実験を行った. 数值解析により得られた結果から, 三次元的流動特性, 特に逆流長さを定量的に評価した。 また，伝熱特性な らびに性能評価も行った。

\section{主要な記号の説明}

$a:$ 流体の温度伝導率 $\left(\mathrm{m}^{2} / \mathrm{s}\right)$

$C_{p}:$ 流体の定圧比熱 $[\mathrm{J} /(\mathrm{kg} \cdot \mathrm{K})]$

$G r:$ グラスホフ数 $=g \beta L^{3}\left|T_{w}-T_{0}\right| / v^{2}$

$g:$ 重力加速度 $\left(\mathrm{m} / \mathrm{s}^{2}\right)$

$h:$ 熱伝達係数 $\left[\mathrm{J} /\left(\mathrm{m}^{2} \cdot \mathrm{s} \cdot \mathrm{K}\right)\right]$

$L:$ 流路の一辺の長さ $(\mathrm{m})$

$l_{\text {rev }}:$ 流路方向の逆流域長さ $(\mathrm{m})$

$N u:$ ヌッセルト数 $=h L / \lambda$

$N u_{a v}$ : 全壁面の平均ヌッセルト数

$p:$ 圧力 $\left(\mathrm{N} / \mathrm{m}^{2}\right)$

$\operatorname{Pr}:$ プラントル数 $=v / a$

$R a:$ レーレー数 $=G r \cdot P r$

$R e:$ レイノルズ数 $=u_{0} L / v$

$R i:$ リチャードソン数 $=G r / R e^{2}$

$t:$ 時間 $(\mathrm{s})$

$T:$ 温度 $\left({ }^{\circ} \mathrm{C}\right)$

$T_{b}:$ 混合平均温度 $\left({ }^{\circ} \mathrm{C}\right)$

$T_{f}$ : 壁の隣のメッシュの流体の温度 $\left({ }^{\circ} \mathrm{C}\right)$

$T_{w}:$ 壁面温度 $\left({ }^{\circ} \mathrm{C}\right)$

$T_{0}:$ 流体の流入温度 $\left({ }^{\circ} \mathrm{C}\right)$

$u, v, w: x, y, z$ 方向の速度成分 $(\mathrm{m} / \mathrm{s})$

$u_{0}:$ 流体の流入平均速度 $(\mathrm{m} / \mathrm{s})$

$x, y, z:$ 座標 $(\mathrm{m}),(\mathrm{mm})$

$\Delta x, \Delta y, \Delta z:$ メッシュ間隔 $(\mathrm{m}),(\mathrm{mm})$

$\beta:$ 体積膨張率 $\left(\mathrm{K}^{-1}\right)$

$\lambda:$ 流体の熱伝導率 $[\mathrm{J} /(\mathrm{m} \cdot \mathrm{s} \cdot \mathrm{K})]$

$\mu:$ 流体の粘性係数 $[\mathrm{kg} /(\mathrm{m} \cdot \mathrm{s})]$

$v:$ 動粘性倸数 $\left(\mathrm{m}^{2} / \mathrm{s}\right)$

$\rho:$ 流体の密度 $\left(\mathrm{kg} / \mathrm{m}^{3}\right)$

$\tau_{w}:$ 壁面せん断応力 $\left(\mathrm{N} / \mathrm{m}^{2}\right)$
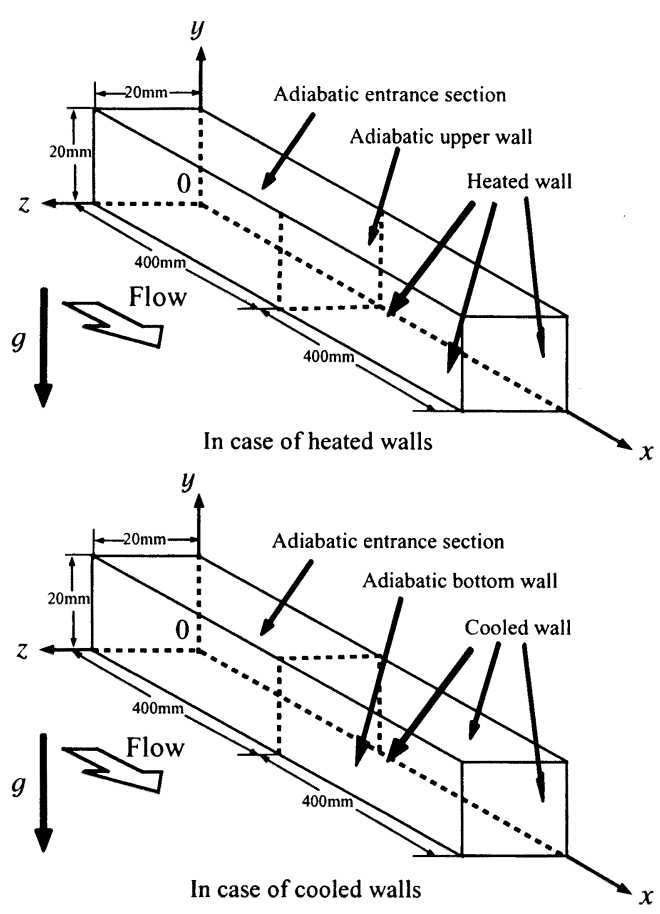

Fig. 1 Coordinate system

\section{1. 数 值 解 析}

1 11 解析モデル 図 1 に本実験に用いた解析モ デルを示す. 座標系は三次元直交座標系 $(x, y, z)$ とし, 重力は $y$ 軸負の向きにかかっているものとする．作動 流体は水とした．流路は, $20 \mathrm{~mm} \times 20 \mathrm{~mm} \times 800 \mathrm{~mm}$ の 水平正方形管とし，流路入口から $400 \mathrm{~mm}$ までの区間 を断熱助走路とした. 助走路部より下流側は, 加熱条 件では，上壁を断熱壁，側壁及び下壁を $T_{w}=60^{\circ} \mathrm{C} の$ 加熱壁, 冷却条件では, 下壁を断熱壁, 側壁及び上壁 を $T_{w}=5^{\circ} \mathrm{C}$ の冷却壁とした．なお，本解析で上述の壁

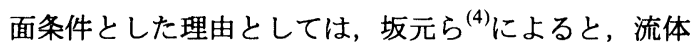
が加熱される条件では，上壁側付近の流体は側壁等に よって既に暖められており，上壁面上での熱伝達はあ まり行われず，複合対流にほとんど影響を与えないと いうことから, 可視化実験を考慮して, 三方加熱・冷 却条件とした。作動流体の流入温度は, 加熱条件では

Table $1 \mathrm{Ri}$ and $\mathrm{Pr}$ for fluid temperatures

\begin{tabular}{|c|c|c|c|c|c|c|c|c|c|}
\hline$T_{0}\left({ }^{\circ} \mathrm{C}\right)$ & 10 & 15 & 20 & 25 & 30 & 35 & 40 & 45 & 50 \\
\hline $\operatorname{Pr}$ & 9.36 & 8.06 & 6.94 & 6.06 & 5.41 & 4.80 & 4.38 & 3.98 & 3.57 \\
\hline$R i\left(T_{u^{\prime}}=60^{\circ} \mathrm{C}\right)$ & 20.58 & 39.88 & 62.78 & 87.39 & 105.89 & 126.18 & 133.67 & 129.30 & 114.65 \\
\hline$R i\left(T_{u^{\prime}}=5^{\circ} \mathrm{C}\right)$ & 2.06 & 8.86 & 23.54 & 49.94 & 88.24 & 151.42 & 233.91 & & \\
\hline
\end{tabular}


$T_{0}=10 \sim 50^{\circ} \mathrm{C}$, 冷却条件では $T_{0}=10 \sim 40^{\circ} \mathrm{C}$ の $5^{\circ} \mathrm{C}$ 毎に 計 16 条件行った. 本解析における流入温度と $R i, \operatorname{Pr}$ と の対応表を表 1 に示す. なお, 作動流体の物性值の参 照温度は流入温度 $T_{0}$ とした．流路入口には, $R e=100$ の層流の発達した速度分布を与え ${ }^{(13)}$, 出口では, 速度 及び温度の勾配を零とし, 壁面では流体は滑らないも のとした.

1.2 数值解析 計算に用いた流れとエネルギー に関する基礎法的式を次に示す.

連続の式

$$
\frac{\partial u_{i}}{\partial x_{i}}=0
$$

運動方程式

$$
\begin{aligned}
& \frac{\partial u_{i}}{\partial t}+\frac{\partial u_{j} u_{i}}{\partial x_{j}}=-\frac{1}{\rho} \frac{\partial p}{\partial x_{i}}+\frac{\partial}{\partial x_{j}}\left(v \frac{\partial u_{i}}{\partial x_{j}}\right)-K_{i} \\
& \text { ただし, } K_{1}, K_{3}=0, K_{2}=g \beta\left(T-T_{0}\right) \\
& \text { エネルギー式 } \\
& \rho c_{p} \frac{\partial T}{\partial t}+\rho u_{i} c_{p} \frac{\partial T}{\partial x_{i}}=\frac{\partial}{\partial x_{i}}\left(\lambda \frac{\partial T}{\partial x_{i}}\right)
\end{aligned}
$$

(添字は, Einstein の総和規約を適用する)

運動方程式中の浮力項には Boussinesq 近似を用いてい る. 初期条件として, 時間 $t=0$ のとき, 全領域に発達 した速度分布と流入温度と同じ温度を与えた。 また, 作動流体である水の熱伝導率および動粘性係数は, 温 度の三次式で与えることにより温度依存性を考慮した。 なお，熱放射は無視した。

速度成分と圧力の計算には圧力補正法 (SIMPLE) ${ }^{(14)}$ を使用し, 圧力差のポアソン式を解き, 質量保存則 を満足する速度場を求めた. また, 対流項の離散化 には数值粘性の影響の少ない QUICK ${ }^{(15)}$ を使用した. 格子には等間隔スタガード格子を使用し, 格子数は $800(x) \times 20(y) \times 20(z)=320000$ とした. 本解析で用い たコードは, 上述の格子数で格子解像度の影響がない ことや，そのコードを用いて $G r / R e^{2}=0$ の場合のヌッ セルト数の発達值を求めた結果が理論值と一致するこ とが既に示されている(2). それらを踏まえ，本数值計 算結果の有効性を確認した. 計算は時間発展で行い, 時間間隔は $\Delta t=0.01$ 秒とした. なお, ヌッセルト分布 より 200 秒 300 秒で準定常解が得られていることを 確認しており, 本研究では, 定常状態の現象として議 論する.

\section{2. 可視 化 実 験}

実験装置の概略を図 2 に示す. 流路寸法は $20 \mathrm{~mm} \times$ $20 \mathrm{~mm} \times 800 \mathrm{~mm}$ と数值解析と同寸法とした. 貯水槽に 蓄えられた水は温度制御装置で温度を一定に保ち，ポ ンプにより上流側混合槽一と揚水する. 揚水する水量 は，バルブにて調節した。流路には，上流と下流に設

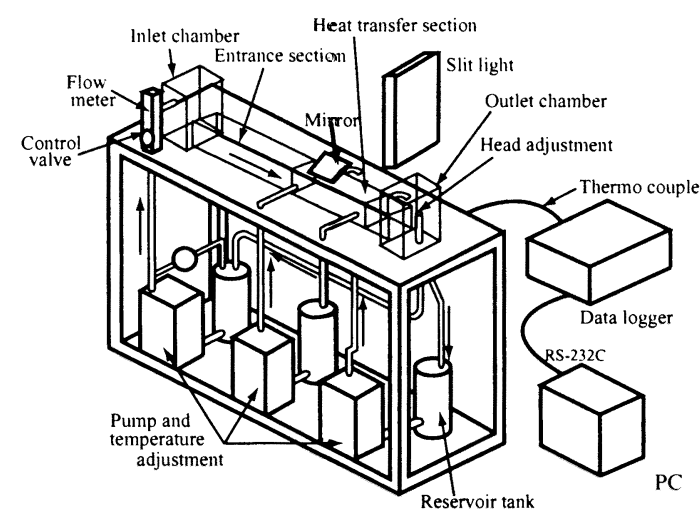

Fig. 2 Experimental apparatus

置した各混合槽のヘッド差を利用して送水し，ヘッド 差は，下流側混合槽内のオーバーフローパイプの高さ により調節した.オーバーフローパイプからあふれた 水は貯水槽に戻り，循環する構造とした。

非加熱助走路は透明アクリル板で作成し, 周囲から 流れを可視化できるようにした．また，伝熱部は，加 熱条件では上壁を，冷却条件では下壁をアクリル板で 作成した．伝熱面は，銅ブロックを削りだして作成し， 周囲に恒温水を循環させて壁面温度を調節した．また， 流入温度, 壁面温度は熱電対にて計測を行った。

可視化試薬にはウラニンの水溶液 (10ppm 程度) を 用い, 試薬を入れた容器にホースを介して直径 $1 \mathrm{~mm}$ の細管を取り付け，この細管を助走路入口部から挿入 し, 可視化試薬を注入した. なお細管の取り付け位置 は, 側壁から $2 \mathrm{~mm}$, 下壁から 5, 10, $15 \mathrm{~mm}$ の 3ヶ所の 位置とした. 試薬注入量は容器の高さを変化させるこ とにより調節した. なお，実験装置は暗室内に設置し， 照明には八ログン光源によるスリット光を用いた．

可視化実験における流入条件 $(R e=100)$ 及び壁面 温度 $\left(T_{W}=60^{\circ} \mathrm{C}, 5^{\circ} \mathrm{C}\right)$ は，数值解析と同じとした. な お, 流動状態は 413 万画素のデジタルカメラで撮影 した.

\section{3. 解析結果および検討}

3.1 流動状況 流入温度の相違による三次元的 な流動機構の変化について検討するために，代表的に， 図 3 に; 加熱条件の流入温度 $T_{0}=10,20^{\circ} \mathrm{C}\left(T_{u}=60^{\circ} \mathrm{C}\right)$ 之 冷却条件の流入温度 $T_{0}=20,30^{\circ} \mathrm{C}\left(T_{u}=5^{\circ} \mathrm{C}\right)$ の $z=2 \mathrm{~mm}$ からの流跡線図を示す。なお, 図 3(a) は, 流路斜め 上方から見た鳥瞰図, 図 3(b) は, 流路下流側から見 た流路断面泪である.四 3(a)において，加熱の条件の $T_{0}=10^{\circ} \mathrm{C}$ では，加熱開始部付近で，主流が下壁に问から 


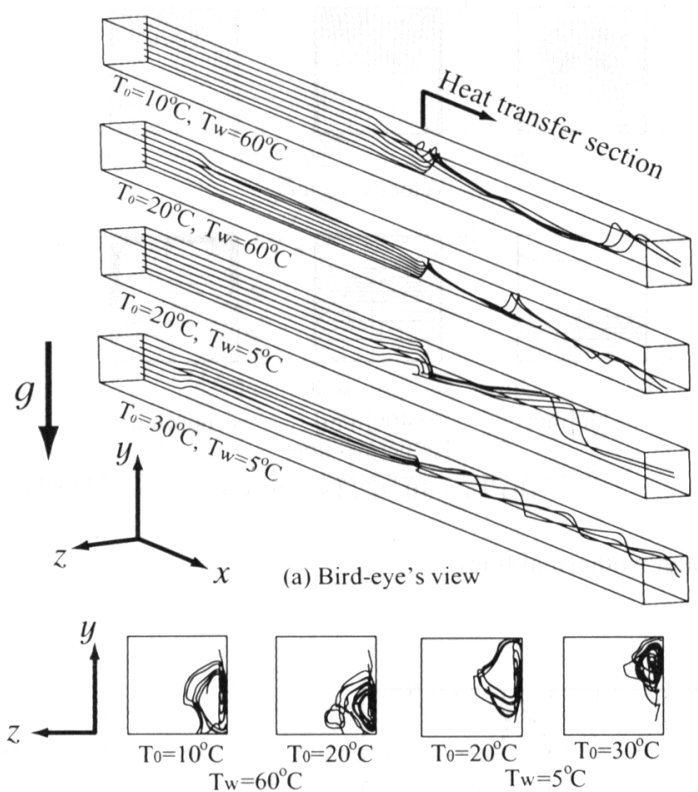

(b) Back view of a cross section

Fig. 3 Streak lines

てその流動方向を変え, 側壁に沿って上昇し, 流れ方 向に軸を持つ、スパイラルな流れを形成する。また， ここでは，そのスパイラルな流れは，2 回転となる. この 1 つ目のスパイラルまでの上壁に現れている空隙 では, 逆流が生じている. $R i$ が大きくなる $T_{0}=20^{\circ} \mathrm{C}$ で は，主流が，下壁に向かって流動方向を変える位置が， より上流入伸張し, 逆流が生じている領域も大きくな る.また, スパイラルな流れも 3 回転となり, $T_{0}=10^{\circ} \mathrm{C}$ と比べて強くなる. 一方, 冷却条件の, $T_{0}=20^{\circ} \mathrm{C}$ では,
冷却開始部付近で，主流が上壁に向かってその流動方 向を変え，側壁に沿って下降することにより，加熱時 とは逆回転のスパイラルな流れを形成する。なお，冷 却開始部付近の下壁上に現れる空隙内も加熱時と同様 に逆流が生じている. Ri が大きくなる $T_{0}=30^{\circ} \mathrm{C}$ では, その逆流の生じている空隙がより上流側へと伸展し, スパイラルな流れも強くなる. 図 3(b) を見ると, 加 熱時では，上壁面上に現れた逆流の影響により，スパ イラルな流れの中心は，流路の中央部よりやや下壁側 に存在し, Ri が增大すると, より下壁側へ近づく. 一 方，冷却時では，下壁面上に逆流が現れるため，スパ イラルの中心は上壁側に現れる.

図 4 に, 代表的に, 冷却時における流入温度が $30^{\circ} \mathrm{C}$ の場合の可視化写真と数值計算結果から得られた流跡 線図を示す. 図 4(a) が断熱助走路側方からの, 図 4(b) が流路下流側からの図である. 図 4(a) の可視化写真で は, 伝熱流路で生じた逆流が下壁に沿って上流側に伸 張していることが確認できる.この流れは, 数值解析 による流跡線図においても生じており, その逆流域の 長さもほぼ一致する．流路断面では, 図4(b)に見られ るように，流路中央部よりやや上壁側でスパイラルな 流れを形成し，数値計算結果とほぼ同様な流れとなる.

さらに流動状況を検討するために, 四 5 に助走路部 $(x=200[\mathrm{~mm}])$, 伝熱開始部 $(x=400[\mathrm{~mm}])$, 伝熱部 $(x$ $=600[\mathrm{~mm}])$ における流路断面内の速度べクトルと等 温線を示す.なお，図の (a) は加熱条件 $\left(T_{0}=20^{\circ} \mathrm{C}, T_{w}\right.$ $\left.=60^{\circ} \mathrm{C}\right)$, (b) は冷却条件 $\left(T_{0}=30^{\circ} \mathrm{C}, T_{w}=5^{\circ} \mathrm{C}\right)$ の場合 である. 加熱条件である図 5(a) の $x=200[\mathrm{~mm}]$ の速 度ベクトル図では, 上壁面上の流体が側壁方向一移動 し, わずかに下降した後, 流路中心部一と流動する.

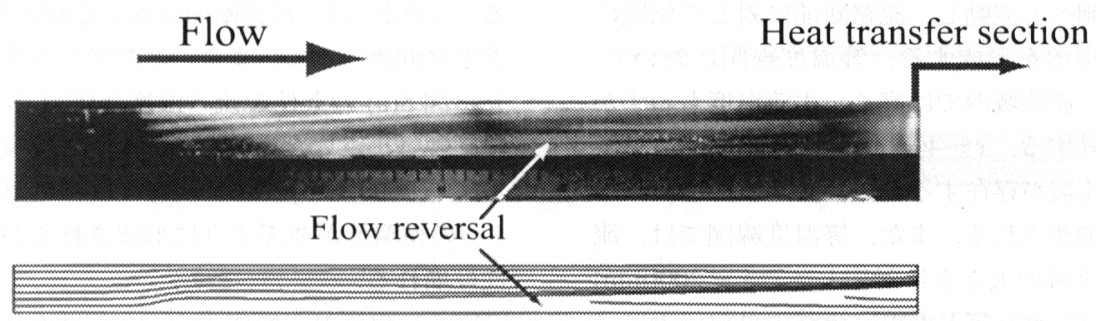

(a) Side view of an entrance section
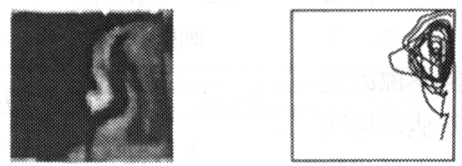

(b) Back view of a cross section

Fig. 4 Visualization of flow reversal by dye-injection method and numerical analysis $\left(T_{0}=30^{\circ} \mathrm{C}, T_{u}=5^{\circ} \mathrm{C}\right)$ 

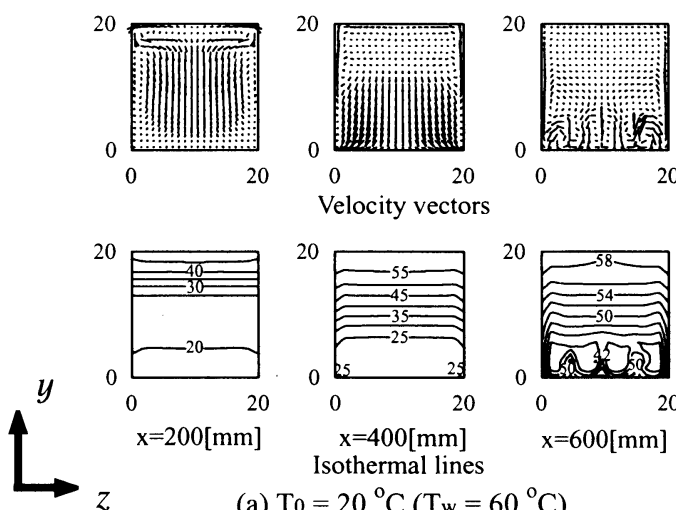

(a) $\mathrm{T} 0=20{ }^{\circ} \mathrm{C}\left(\mathrm{T}_{\mathrm{w}}=60{ }^{\circ} \mathrm{C}\right)$
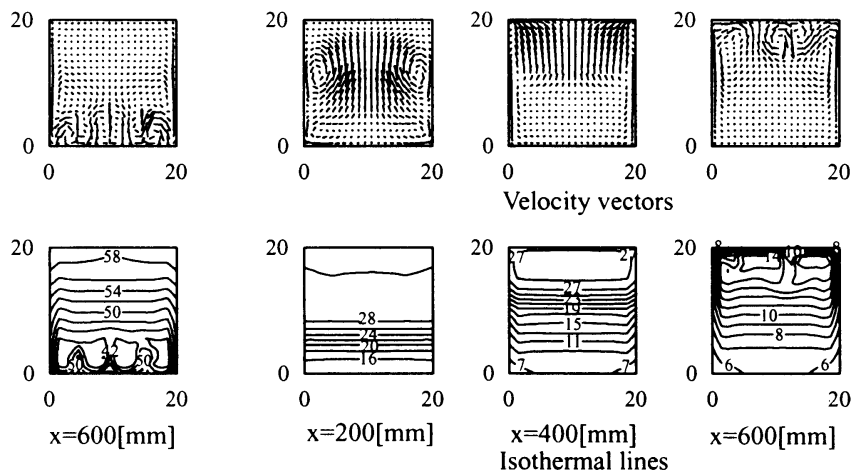

(b) $\mathrm{T}_{0}=30{ }^{\circ} \mathrm{C}\left(\mathrm{T}_{\mathrm{w}}=5^{\circ} \mathrm{C}\right)$

Fig. 5 Velocity vectors and isothermal lines

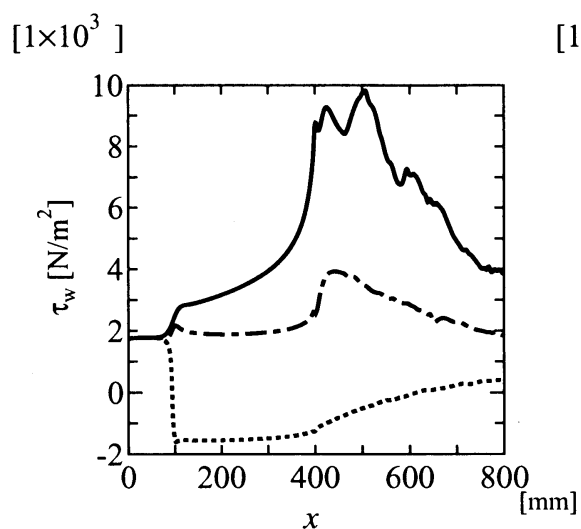

(a) $\mathrm{T}_{0}=20^{\circ} \mathrm{C}, \mathrm{T}_{\mathrm{w}}=60^{\circ} \mathrm{C}$ $\left[1 \times 10^{3}\right]$

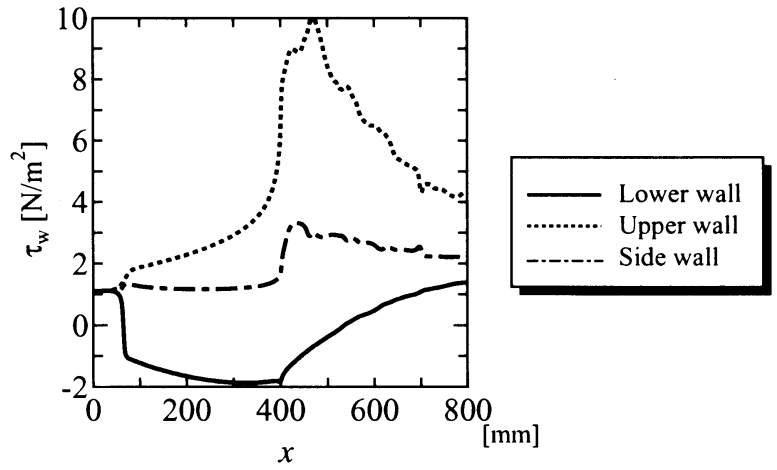

(b) $\mathrm{T}_{0}=30^{\circ} \mathrm{C}, \mathrm{T}_{\mathrm{w}}=5{ }^{\circ} \mathrm{C}$

Fig. 6 Shearing stress on the walls

なお，この位置は逆流域である．主流は逆流域を避け るように下壁側へと流動し，流路断面に対して側壁に 沿って弱い循環流を形成する．等温度線図において， 流体の温度は, 逆流域内では高く, 主流温度もわずか ではあるが上昇する． $x=400[\mathrm{~mm}]$ では，流路中央部 付近にまで逆流域が存在するため, 流路下部を流れる 主流はさらに加速される。また，等温度線図では，流 路断面内の逆流域の大きさに対応して,$x=200[\mathrm{~mm}]$ の上壁付近に見られた等温度線は流路中央部付近にま で広がる. $x=600[\mathrm{~mm}]$ では, 流路下壁面付近で, 横 一列に 4 つの循環流が並ぶように形成されている。 こ れは, 等温度線図からも分かるように, 流路下部の流 体の温度が低く，壁面と流体との温度勾配が他の場所 と比べて大きいため, その部位でのみ循環流を形成し たものと考えられる。一方，冷却条件である図 5(b) の $x=200[\mathrm{~mm}]$ の速度ベクトル図を見ると, 逆流域が下
壁に沿って形成されるため，主流は上壁側へと流動す る. したがって, 流路断面に対する循環流は, 加熱の条 件と逆向きとなる. また，このときの流入温度は $30^{\circ} \mathrm{C}$ と, 図 5(a) の条件の流入温度 $20^{\circ} \mathrm{C}$ よりも高く, 流体 の粘性は小さいため, 流路断面内の循環流は大きくな る. $x=600[\mathrm{~mm}]$ では, 流路上壁面付近で, 横一列に 4 つの循環流が並ぶように形成されるが，左右の対称 性は崩れる。

図 6 に壁面せん断応力を示す，壁面せん断応力は次 式から算出した。

側壁面上のせん断応力

$$
\tau_{u}=\frac{1}{L} \int_{0}^{L} \mu \frac{2.0 u_{f}(y)}{\Delta z} d y
$$

上下壁面上のせん断応力

$$
\tau_{u^{\prime}}=\frac{1}{L} \int_{0}^{L} \mu \frac{2.0 u_{f}(z)}{\Delta y} d z
$$

図 6(a) は加熱条件の $T_{0}=20^{\circ} \mathrm{C}, T_{u^{\prime}}=60^{\circ} \mathrm{C}$, 図 6(b) 


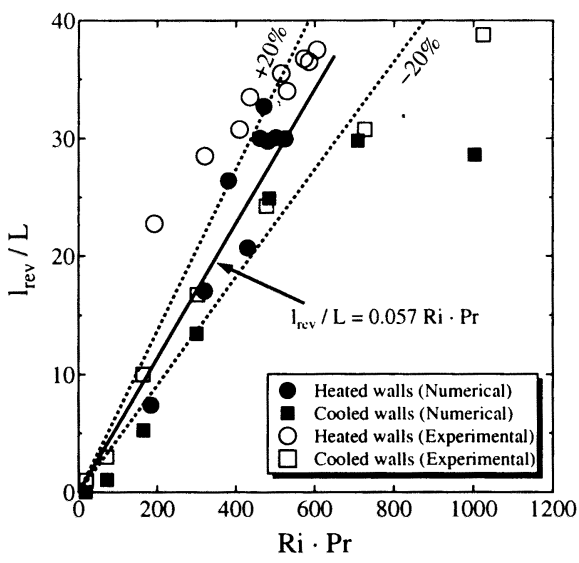

Fig. 7 Relationship between reversal flow and $\mathrm{Ri} \cdot \mathrm{Pr}$

は冷却条件の $T_{0}=30^{\circ} \mathrm{C}, T_{w}=5^{\circ} \mathrm{C}$ であり, 主流方向速 度より求めた局所せん断応力を横方向に平均した值を 示している. 図 6(a) の上壁側では, 壁面せん断応力 は，xがおよそ 100〜 600[mm] の範囲で負の值を取り， 逆流していることが分かる. また, 下壁側では， $x$ が $100[\mathrm{~mm}]$ の位置から增加し, $x$ が 400 500[mm] 付近 でピークを取り，减少する。これは，主流が逆流域を 避けるように下壁側へと流れが加速されるため，下壁 面上のせん断応力が增大寸るからである. 側壁側では, 逆流域と主流により，せん断応力が正負両方とも持つ ため, 平均值としては比較的小さな值となる. 一方, 図 6(b) では，下壁面上に逆流域が存在するため，下壁 面上のせん断応力は, $x$ がおよそ 30〜 500[mm] の範囲 で負の值を取る. また，それに伴い，上壁側のせん断
応力は增大する。

次に，逆流域の長さについて検討するために，図７ に各入口温度における $R \boldsymbol{i} \cdot \operatorname{Pr}$ と流路内の逆流域の長さ を $l_{r e v}$ として無次元逆流長さ $l_{r e v} / L$ をプロットした図 を示す，なお，図における丸印は加熱条件，四角印は 冷却条件を示しており, 黒塗りは数值計算結果, 白抜 きは可視化実験結果である. また，数值解析結果にお ける逆流開始点は, $y$ 方向の $u$ 速度勾配が零 $(\partial u / \partial y$ =0) となる位置とした. 全体的な傾向として, 逆流域 の長さは, $R i \cdot P r$ に対してほほ直線的に増大する．な お, $R i \cdot P r=R a / R e^{2}(R a:$ レーレー数) であり, $R i$ のみ でなく $P r$ を含めることにより值が収束する.ここ で, $R i \cdot \operatorname{Pr}$ が 600 以上の条件では，この直線的な增加 から離れた值を取っている，この条件では，逆流域は 流路入口付近にまで達しており, 助走路が本条件より も長ければ，逆流域はより上流側へと伸張すると思わ れる. また, 可視化実験の加熱条件では, 他の条件と 比較し，逆流域の長さは大きな值を取っている。これ は，加熱壁の温度が $60^{\circ} \mathrm{C}$ と高く，流路を形成してい るアクリル内の熱伝導が無視できなくなり，断熱条件 のはずの助走路内においても主流に対し熱伝達が行わ れたため, 逆流域を伸張させたと考えられる. 可視化 実験における加熱条件及び $R i \cdot \operatorname{Pr}$ が 600 以上の条件を 除いて整理すると，以下の数式が得られる

$$
l_{\text {rev }} / L=0.057 R i \cdot P r
$$

上式は，定性的に逆流長さの傾向を示している．精度 的には低い $R i \cdot \operatorname{Pr}$ で誤差は大きいが, 高い $R i \cdot \operatorname{Pr}$ で は $\pm 20 \%$ 以内に入り，適用範囲は $0 \leqq R i \cdot P r<600$ で ある。

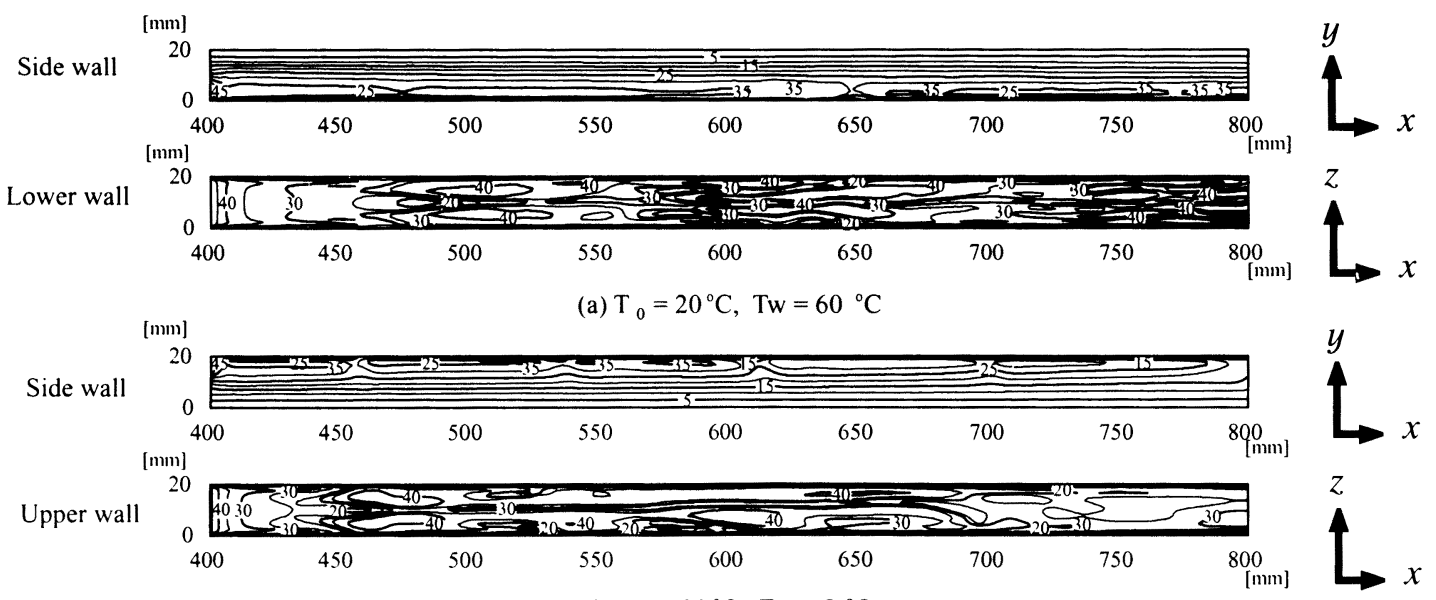

(b) $\mathrm{T}_{0}=30^{\circ} \mathrm{C}, \mathrm{TW}=5{ }^{\circ} \mathrm{C}$

Fig. 8 Local Nusselt number on the walls 


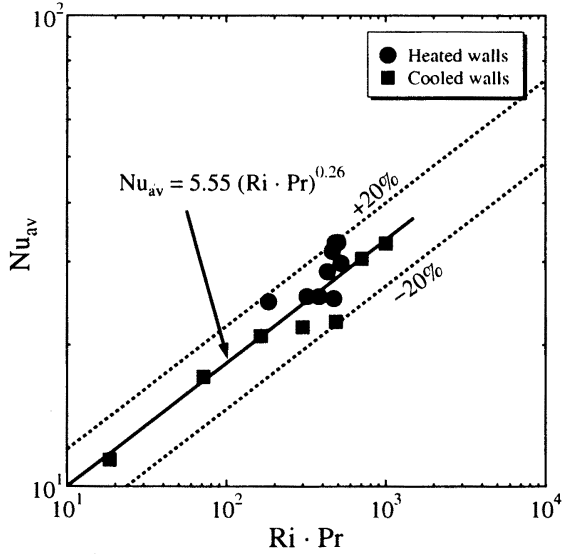

Fig. 9 Relationship between average Nusselt and $R i \cdot P r$

3.2 熱伝達伝熱状態を検討するため, 図 8 に 流路壁面上の局所ヌッセルト数を示す. なお, 図 8(a) は加熱条件の流入温度 $T_{0}=20^{\circ} \mathrm{C}$ の場合, 図 8(b) は冷 却条件の流入温度 $T_{0}=30^{\circ} \mathrm{C}$ の場合である. 本検討に 用いるヌッセルト数は, 次式から算出した.

左右側壁面上のヌッセルト数

$$
N u=\frac{2 L}{\Delta z} \frac{\left|T_{w}-T_{f}\right|}{T_{w}-T_{b}}
$$

上下壁面上のヌッセルト数

$$
N u=\frac{2 L}{\Delta y} \frac{\left|T_{w}-T_{f}\right|}{T_{w}-T_{b}}
$$

なお, 混合平均温度は, 次式から求めている.

$$
T_{b}=\frac{\sum|u \cdot T|}{\sum|u|}
$$

図 8(a) では，加熱開始付近の上壁側に逆流域が存在 するため, 上壁付近の加熱開始直後のヌッセルト数は 下壁付近の值と比較して小さい. 下壁面上のヌッセル 卜数は, スパイラルな流れに対応して, 流体が壁面に 衝突する所で, 局所ヌッセルト数も高くなっている. また, 自然対流による二次流が強いため, 流路下流側 一沿って, 左右対称性は崩れている. 一方, 冷却条件 となる図 8(b) では, 冷却開始付近の下壁よりに逆流域 が存在するため, 下壁に近い側壁面上の冷却開始直後 のヌッセルト数は，上壁付近の值と比較して小さくな る. また，上壁面上のヌッセルト数は，流れに対応し た分布を取り，加熱と同様に，左右の対称性は崩れて いる.

図 9 に流路の伝熱壁全体の平均ヌッセルト数 $N u_{a v}$ と各入口温度における $R i \cdot \operatorname{Pr}$ の関係を両対数で示す. 四における○は加熱条件, 口は冷却条件の值である. $R i \cdot \operatorname{Pr}$ が増加するとともに, $N u_{a v}$ は増加傾向を示す.

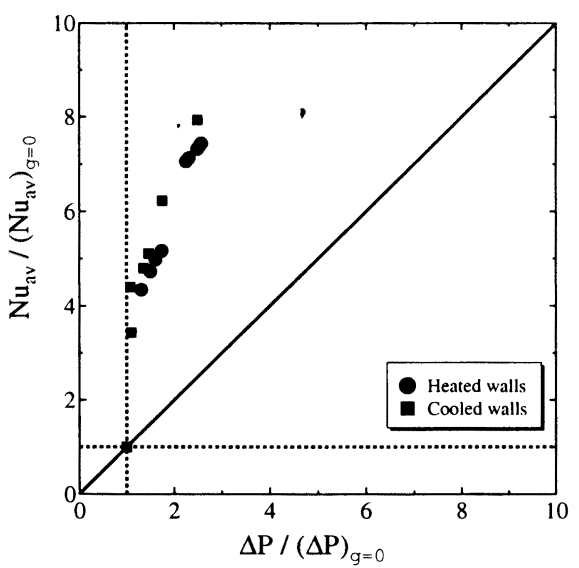

Fig. 10 Thermal performance

本計算範囲において最小自乗法近似により整理して， 以下の式を得た.

$$
N u_{a v}=5.55(R i \cdot P r)^{0.26}
$$

本解析範囲内での上式における誤差は最大 $\pm 20 \%$ であ り，適用範囲は $20 \leqq R i \cdot P r \leqq 1000$ である．低レイノ ルズ数，低グラスホフ数，すなわち，強制対流，自然 対流が共に層流状況で複合対流を構成すれば, 流動状 況とも対応して，熱伝達においても $G r / R e^{2}$ が支配的 となり, $R e$ が変化しても式 (10) で十分整理可能であ る. なお, $R i \cdot \operatorname{Pr}=G r \cdot \operatorname{Pr} / \operatorname{Re}^{2}$ であり，指数の 0.26 乗 は，ほぼ $1 / 4$ 乗であるため， $G r^{1 / 4}$ となり，自然対流 の依存性が強い特性が現れている.

伝熱管の伝熱性能を検討するため, 図 10 に，平均ヌ ッセルト数と強制対流のみの值との比をとった熱伝達増 加率 $N u_{a v} /\left(N u_{a v}\right)_{g=0}$ を繸軸に, 圧損増加率 $\Delta P /(\Delta P)_{y=0}$ を横軸として示す．本数值解析結果では，圧損増加率 が増大すると熱伝達増加率も増大し，その增大割合は， 圧損増加率よりも熱伝達增加率の方が大きい．また， 本条件範囲内では， $R i \cdot \operatorname{Pr}$ の増大とともに圧損増加率 及び熱伝達増加率とも増大した．功刀ら ${ }^{(3)}$ の研究では， $0 \leq R i \leq 50$ の篑囲に伝熱性能の最適条件があると報告 しているが，本解析結果では， Ri·Pr が大きい程，良 い伝熱性能となる傾向を示している．この結果の相違 は，物性值の温度依存性の考慮の有無によると考えら れる. 今後,きめこまかい条件について検討する必要 がある.

\section{おわりに}

水平正方形流路内の複合対流について, 流体が伝熱 壁面によって加熱, 冷却される場合の 2 種類の条件に 対し, 三次元楕円型数值解析及び可視化実験を行った 
結果, 以下の結論を得た.

（1）数值計算において流体が加熱される条件では, 伝 熱開始部近傍の上壁面上に，流体が冷却される条 件では，下壁面上に逆流が形成される．またこ の逆流は, 可視化実験においても確認された.

(2) 逆流域の長さは, $R i \cdot \operatorname{Pr}$ の増大とともにほぼ直線 的に增大する.

（3）浮力誘起に伴う流れが伝熱面に衝突する箇所で局 所ヌッセルト数は增大する.

(4) 全壁面の平均ヌッセルト数は $R i \cdot \operatorname{Pr}$ の増大ととも に指数関数的に増大し，その推算式を導出した。

(5) 本条件範囲内では, $R i \cdot \operatorname{Pr}$ の増大とともに熱伝達増 加率 $N u_{a v} /\left(N u_{a v}\right)_{y=0}$ と圧損增加率 $\Delta P /(\Delta P)_{g=0}$ は 増大し，その増大割合は，压損増加率よりも熱伝 達增加率の方が大きい.

\section{文献}

(1) Gebhart, B., Jaluria, Y., Mahajan, R. L. and Sammakia, B., Buoyancy Induced Flows and Transport, (1988), pp.467543, Hemisphere Publishing Corporation.

（2）功刀資彰・一宮浩市・坂元美定, 等温加熱下の複合対流熱 伝達に関する数值解析, 機論, 60-572, B (1994), pp.13931400.

（3）功刀資彰 - 坂元美定 - 一宮浩市, 逆流を伴う等温水平 正方形流路内の層流複合対流熱伝達, Thermal Sci. Eng., 2-3, (1994), pp.9-18.

(4) 坂元美定 - 功刀資彰・一宮浩市, 等温水平管内の複合対 流による逆流域の数値解析と可視化実験, 可視化情報, 16-63, (1996), pp.253-258.

(5) 内藤悦郎・長野靖尚, 傾斜平行平板間の層流助走区間にお ける自然・強制複合対流熱伝達（第 1 報，上昇流におけ る流動と熱伝達）, 機論, 54-479, B (1988), pp.155-162.
（6）内藤悦郎 - 長野靖尚, 傾斜平行平板間の層流助走区間に おける自然・強制複合対流熱伝達（第 2 報，下降流にお ける流動と熱伝達），機論, 54-505, B (1988), pp.24992507.

(7) Cheng, C. H., Wang, C. J. and Aung W., Buoyancy Effect on the Flow Reversal of Three-Dimensional Developing Flow in a Vertical Rectangular Duct - A Parabolic Model Solution., Trans. ASME, J. Heat Transf., 117-1, (1995), pp.238-241.

(8) Cheng, C. H., Wang, C. J. and Aung W., BuoyancyAssisted Flow Reversal and Convective Heat Transfer in Entrance Region of a Vertical Rectangular Duct, Int. J. Heat Fluid Flow, 21, (2000), pp.403-411.

(9) Barletta, A., Fully Developed Mixed Convection and Flow Reversal in a Vertical Rectangular Duct with Uniform Wall Heat Flux, Int. J. Heat Mass Transf., 45, (2002), pp.641-654.

（10）王煤·辻俊博 ·長野靖尚, 液体金属の水平円管内自然·強 制複合対流の数值解析, 機論, 58-555, B (1992), pp.33823388.

(11) Wang, M., Tsuji, T. and Nagano, Y., Mixed Convection with Flow Reversal in the Thermal Entrance Region of Horizontal and Vertical Pipes, Int. J. Heat Mass Transf., 37-15, (1994), pp.2305-2319.

(12) Ichimiya, K. and Toriyama, K., Effect of Flow Reversal on Wall Heat Transfer in Three-Dimensional Mixed Convection, The 13th International Symposium on Transport Phenomena, (2002), pp.281-284.

(13) Shah, R. K. and London, A. L., Laminar Flow Forced Convection in Ducts, Advances in Heat Transf., (1978), pp.197, Academic Press.

(14) Patanker, S. V., Numerical Heat Transfer and Fluid Flow, (1980), pp.11-150, Hemisphere Publishing Corporation.

(15) Leonard, B. P., Computer Method in Fluid, (1980), pp.159-195, Pentech Press, Plymousth. 